\title{
Faktor-Faktor Yang Mempengaruhi Jumlah Produksi Usaha Tambak Ikan Di Gampong Batuphat Barat Kecamatan Muara Satu Kota Lhokseumawe
}

\author{
Aries Munandar ${ }^{* a}$, Cut Putri Mellita Sari ${ }^{* b}$ \\ *Fakultas Ekonomi dan Bisnis Universitas Malikussaleh \\ a Corresponding author: armun301@gmail.com \\ b cmellita0674@gmail.com
}

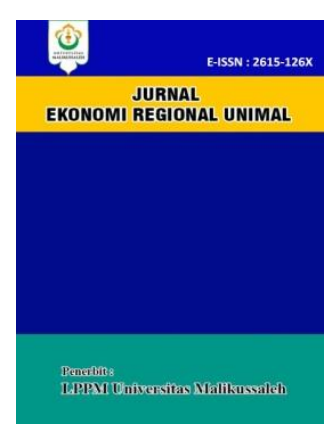

ARTICLE INFORMATION

Keywords:

Total Production, Capital, Land Area and Labor

\section{A B S T R A C T}

The purpose of this study is to determine the effect of capital, land area and labor on the production of fish ponds in the village of Batuphat Barat, Muara Satu Subdistrict, Lhokseumawe City. This study uses primary data and Multiple Linear Regression. The result of the study showed that partially the Capital had a positive and significant effect on the amount of fish farm production in the village of Batuphat Barat, Muara Satu Subdistrict, Lhokseumawe City, while the Land Area and Labor had no significant, but positive affect the number of fish farm production in the village of Batuphat Barat, Muara Satu Subdistrict, Lhokseumawe City. Simultaneously the Capital, Land Area and Labor together has a significant effect on the amount of fish ponds business production in the village of Batuphat Barat, Muara Satu Subdistrict, Lhokseumawe City.

\section{PENDAHULUAN}

Di wilayah Indonesia, sepanjang pantainya yang sangat potesial sebagai lahan untuk tambak ialah sebesar 1,2 juta Hektar. Yang digunakan sebagai lahan tambak udang hanya $300.000 \mathrm{Ha}$ (Rusmiyati dalam, Humamy, 2013). Sisanya masih lahan tidur, artinya peluang guna membangunkan potensi pada lahan tambak tidur itu guna budidaya pada usaha tambak masih sangat terbuka lebar. Khususnya di Provinsi Aceh.

Kemudian guna memperoleh hasil maksimal pada investasi sektor ini juga harus sangat memperhatikan lingkungan sebagai lahan yang akan digunakan dan juga termasuk luas lahan yang akan digunakan, hal ini dikarenakan berbagai kegagalan yang pernah menimpa petani tambak di Indonesia diduga berawal dari kerusakan lingkungan sebagai lahan tambak yang digunakan. Lingkungan tambak ialah suatu ekosistem dan juga luas pada tambak tersebut memiliki peran yang penting di dalam menjaga kelangsungan hidup organismenya yang dibudidayakan, sehingga jika penurunan daya dukung dari lingkungan dan luas lahan yang dipakai nantinya merupakan hal yang serius dan penting terhadap kelangsungan tingkat produktivitas usaha tambak.

Hal ini terbukti dengan adanya kondisi dimana aktivitas produksi dari budidaya ikan tambak menurun diberbagai daerah di Indonesia, hal ini dikarenakan penerapan dari teknologi budidaya tersebut yang tidak ramah akan lingkungan seperti penggunaan dari eksternal input di dalam proses produksi yang berlebihan khususnya penggunaan dari bahan kimia dan juga obat-obatan sebagai komponen yang mendukung di dalam budidaya. Dampak negatif yang sangat nyata dari penggunaan tersebut ialah menurunnya daya dukung dari tambak dan juga terjangkitnya penyakit khususnya Monodon Baculo Virus (MBV).

Namun tidak untuk di Provinsi Aceh bahwa setiap tahunnya terus mengalami peningkatan produksi dari tahun 2013 jumlah ikan budidaya di Aceh adalah sebesar 46.911,6 Ton dan di tahun 
2017 meningkat menjadi 100.809,4 Ton. Hal ini dikarenakan para petambak di Aceh sangat memperhatikan lingkungan sebagai lahan yang akan digunakan dan juga termasuk luas lahan yang akan digunakan. (Yusminar, 2018). Dan hal ini juga terbukti dalam penelitian terdahulu menurut (Turua et all, 2014) yang menyatakan bahwa luas lahan ialah salah satu faktor yang penting bagi kelangsungan tingkat produktivitas usaha tambak.

Selanjutnya guna mendapatkan hasil maksimal pada sektor ini juga dibutuhkan faktor tenaga kerja, tenaga kerja dibutuhkan dalam hal ini tidak hanya sekedar jumlah dari tenaga kerja yang ada pada usaha tersebut, namun juga keahlian ialah faktor yang juga menentukan guna menghasilkan output yang banyak serta berkualitas. Hal ini terbukti dalam teori menurut (Turua et all, 2014) yang menyatakan bahwa salah satu faktor yang penting bagi kelangsungan usaha tambak.

Kota Lhokseumawe merupakan salah satu kota yang ada di dalam wilayah Provinsi Aceh, di Kota Lhokseumawe meiliki tempat yang strategis dan juga dulunya dijuluki sebagai kota petro dollar ini menjadikan sektor pertanian melalui sub sektor perikanannya salah satu pendorong pertumbuhan ekonomi di Kota Lhokseumawe yang terus berkembang dari tahun ke tahun. Namun wilayah yang tergolong sangat banyak menyumbang besarnya pendorong pertumbuhan ekonomi melalui sektor ini umumnya ialah wilayah yang berada pada pesisir pantai dan wilayah yang banyak lahan tambak, dan wilayah yang termasuk banyak yang memiliki lahan tambak di wilayah Kota Lhokseumawe ialah di Kecamatan Muara Satu.

Gampong Batuphat Barat merupakan salah satu gampong yang berada pada Kecamatan Muara Satu Kota Lhokseumawe, di Gampong Batuphat Barat Kecamatan Muara Satu memiliki penduduk terbesar di Kecamatan Muara Satu yaitu sebesar 6.515 jiwa yang memiliki profesi pekerjaan yang bervariasi, salah satunya adalah memiliki usaha di bidang perikanan tambak yaitu dengan jumlah 30 orang. Pemilik usaha tambak di Gampong Batuphat Barat Kecamatan Muara Satu Kota Lhokseumawe itu sendiri banyak memanfaatkan lahan tambak tersebut untuk memelihara ikan, lahan tambak di daerah tersebut ada yang sekaligus dikelola oleh pemiliknya sendiri dan ada juga yang memperkerjakan orang lain untuk mengelola lahan tambak tersebut. Berikut adalah gambaran data modal, luas lahan dan juga tenaga kerja pada usaha tambak di Batuphat Barat Kecamatan Muara Satu Kota Lhokseumawe.

\begin{tabular}{|c|c|c|c|}
\hline $\begin{array}{r}\text { Modal, Lua } \\
\text { Gampong Bat } \\
\text { Satu }\end{array}$ & $\begin{array}{l}\text { Tab } \\
\text { Lahan } \\
\text { phat Ba } \\
\text { Kota Ll }\end{array}$ & $\begin{array}{l}\text { n Tenage } \\
\text { t Kecam } \\
\text { zseumaw }\end{array}$ & $\begin{array}{l}\text { rja di } \\
\text { Muara }\end{array}$ \\
\hline Modal & $\mathbf{L L}$ & TK & $\mathbf{J P}$ \\
\hline Rp. 200.000 .000 & $2 \mathrm{Ha}$ & 2 Orang & $4.000 \mathrm{Kg}$ \\
\hline Rp. 200.000 .000 & $1 \mathrm{Ha}$ & 2 Orang & $10.000 \mathrm{Kg}$ \\
\hline Rp. 65.000 .000 & 1,2 $\mathrm{Ha}$ & 2 Orang & $2.500 \mathrm{Kg}$ \\
\hline Rp. $\quad 5.000 .000$ & $1 \mathrm{Ha}$ & 1 Orang & $150 \mathrm{Kg}$ \\
\hline Rp. 32.000.000 & $3 \mathrm{Ha}$ & 3 Orang & $5.000 \mathrm{Kg}$ \\
\hline
\end{tabular}

Sumber: Hasil Observasi (2019)

Berdasarkan pada Tabel 1 di atas terlihat bahwa dari modal yang dikeluarkan oleh para pemilik usaha tambak ikan di Gampong Batuphat Barat Kecamatan Muara Satu Kota Lhokseumawe paling besar adalah Rp. 200.000.000 dan yang paling rencah adalah sebesar Rp. 5.000.000. Kemudian jika dilihat dari tabel yang ada di atas terlihat bahwa luas lahan yang dipakai untuk menjalankan usaha tambak ikan di Gampong Batuphat Barat Kecamatan Muara Satu Kota Lhokseumawe paling luas adalah sebesar 3 Ha dan yang paling kecil adalah sebesar $1 \mathrm{Ha}$. Dan selanjutnya jika dilihat dari tabel di atas bahwa tenaga kerja yang dipakai untuk mengelola atau menjalankan usaha tambak ikan di Gampong Batuphat Barat Kecamatan Muara Satu Kota Lhokseumawe paling banyak adalah 3 Orang dan paling sedikit adalah 1 Orang. Kemudian jika dilihat dari tabel di atas bahwa hasil produksi pada usaha tambak ikan di Gampong Batuphat Barat Kecamatan Muara Satu Kota Lhokseumawe paling banyak adalah sebesar $10.000 \mathrm{Kg}$ dan yang paling sedikit adalah sebanyak $150 \mathrm{Kg}$.

Dengan gambaran yang sudah dijelaskan di atas bahwa dengan jumlah modal dan luas lahan yang lebih besar serta tenaga kerja yang lebih banyak tidak menentukan banyaknya jumlah produksi yang dihasilkan nantinya, hal ini dikarenakan jenis tambak ikan yang digeluti oleh petani tambak berbeda-beda, maka dengan itu proses dan mekanisme serta strategi usaha yang dilakukan juga ikut berbeda. Misalnya tambak pada Udang Vaname proses dan mekanismenya berbeda, sehingga memakan modal yang sangat 
besar dibandingkan dengan usaha tambak yang lain, akan tetapi hasil produksi yang diperoleh juga berbeda, terkadang jenis tambak lain yang memerlukan modal lebih kecil dapat menghasilkan jumlah produksi yang lebih banyak, yang artinya tidak selamanya modal yang banyak dapat menghasilkan hasil maksimal sesuai dengan harapan. Hal ini terbukti seperti yang terjadi di lapangan, dengan modal yang sama besar sebesar Rp. 200.000.000, luas lahan yang sedikit berbeda yaitu sebesar $1 \mathrm{Ha}$ dan $2 \mathrm{Ha}$ dan jumlah tenaga kerja sama banyak sebanyak 2 orang namun menghasilkan jumlah produksi yang berbeda. Kemudian ada juga modal yang besar yaitu $\mathrm{Rp}$. 200.000.000 dan modal yang kecil yaitu sebesar Rp. 32.000.000, luas lahan sedikit berbeda yaitu sebesar $2 \mathrm{Ha}$ dan $3 \mathrm{Ha}$, jumlah dari tenaga kerja yang juga sedikit berbeda yaitu sebanyak 2 Orang dan 3 Orang, akan tetapi memiliki hasil yang berbeda dengan modal yang lebih kecil menghasilkan jumlah produksi yang lebih banyak dari pada jumlah produksi yang memiliki modal yang besar. Fenomena ini menunjukan hal yang berbeda dengan teori yang sudah dipaparkan sebelumnya, maka penulis tertarik untuk melakukan penelitian yang berjudul "FaktotFaktor Yang Mempengaruhi Jumlah Produksi Usaha Tambak Ikan di Gampong Batuphat Barat Kecamatan Muara Satu Kota Lhokseumawe".

Berdasarkan penelitian di atas, maka dengan itu tujuan dari penelitian ini ialah untuk mengetahui besarnya pengaruh modal, luas lahan dan juga tenaga kerja terhadap jumlah produksi usaha tambak ikan di Gampong Batuphat Barat Kecamatan Muara Satu Kota Lhokseumawe."

Bagian kedua dari tulisan ini adalah tinjauan teoritis. Pada bagian ketiga dalam tulisan ini dipaparkan metode penelitian. Kemudian, hasil dan pembahasan dipaparkan dalam bagian ke empat. Selanjutnya di bagian ke lima menyampaikan kesimpulan dan saran.

\section{TINJAUAN TEORITIS}

\section{Jumlah Produksi}

Definisi jumlah produksi ialah besarnya jumlah ikan yang dihasilkan oleh usaha tambak dalam sekali panen, dalam satuan $\mathrm{Kg}$. Menurut Rosyidi dalam Habib (2013) produksi ialah setiap usaha yang memperbesar atau menciptakan daya guna barang. Guna dapat melakukan proses produksi, orang tentunya memerlukan bahan baku, tenaga kerja dan juga modal dalam segala bentuknya serta keahlian ataupun skill. Semua unsur tersebut disebut dengan faktor-faktor produksi. Sedangkan produksi ialah kegiatan guna meningkatkan manfaat suatu barang.

Habib (2013) meneliti tentang Analisis FaktorFaktor Yang Mempengaruhi Produksi Jagung. Berdasarkan dari hasil penelitian yang menunjukkan bahwa nilai dari koefisien determinasi $\left(\mathrm{R}^{2}\right)$ pada penelitian ini sebesar 0,99 , yang berarti bahwa pengaruh dari faktor produksi terhadap produksi bisa dijelaskan oleh keempat variabel bebas yaitu sebesar 99\%, selebihnya bisa dijelaskan oleh faktor lainnya yang di luar dari pada penelitian ini. Nilai Fhitung 19,45 > F- tabel 2,78 pada tingkat kepercayaan 95\%, maka dengan itu $\mathrm{H} 1$ diterima dan H0 ditolak. Yang berarti secara serempak memiliki pengaruh nyata antara luas lahan, pupuk, benih dan juga tenaga kerja dengan produksi jagung. Secara parsial benih mempunyai pengaruh nyata terhadap produksi, sedangkan luas lahan, pupuk, dan juga tenaga kerja tidak mempunyai pengaruh nyata terhadap produksi jagung. Dari hasil perhitungan dengan skala hasil diperoleh nilai RTS yaitu 0,98, dengan begitu RTS mempunyai nilai lebih kecil dari satu $(\varepsilon p<1)$, dengan begitu hal ini bisa menunjukkan dari keadaan decreasing return to scale yang artinya penambahan input dari luas lahan, pupuk, benih dan juga tenaga kerja masing-masing ialah $1 \%$ melebihi dari penambahan produksi yaitu sebesar $0,98 \%$.

\section{Modal}

Definisi modal ialah biaya yang dikeluarkan oleh pemilik usaha untuk memperoleh hasil dan biaya tersebut merupakan biaya segala kebutuhan usaha yang diperlukan untuk proses mencapai hasil, dalam satuan Rupiah. Menurut Rosyidi dalam Habib (2013), modal yaitu mencakup uang yang ada di dalam perusahaan guna membeli mesinmesin serta faktor-faktor produksi lainnya. Sedangkan Mankiw dalam Habib (2013) mendefinisikan modal ialah seperangkat sarana yang digunakan oleh pekerja. Schwiedlend dalam Habib (2013), modal meliputi modal di dalam bentuk uang ataupun di dalam bentuk barang.

Susilo (2007) meneliti tentang Analisis 
Ekonomi Usaha Budidaya Tambak Dan FaktorFaktor Yang Mempengaruhi Produksi. Berdasarkan hasil dari penelitian yang menunjukkan bahwa Pendapatan dari usaha budidaya tambak yang ada di Desa Sepatin Kabupaten Kutai Kartanegara ialah Rp. 5.798.235.667,00 permasa panen ataupun rataratanya Rp. 193.274.522,00 per responden. Usaha budidaya udang yang ada di Desa Sepatin Kabupaten Kutai Kartanegara menguntungkan. Hal ini bisa dilihat dari analisis rasio pada keuntungan usaha yaitu RCR > 1 . Kemudian padat penebaran, luas tambak, lama usaha dan juga jumlah tenaga kerja secara simultan mempunyai pengaruh terhadap produksi. Selanjutnya luas tambak secara parsial sangat berbeda nyatanya terhadap produksi. Jumlah tenaga kerja secara parsial berbeda nyatanya terhadap produksi.

\section{Luas Lahan}

Definisi luas lahan ialah besarnya lahan yang dimiliki pemilik usaha tambak ikan untuk melakukan kegiatan usaha tambak, dalam satuan Ha. Menurut Phahlevi (2013) maksud dari lahan ialah tanah terbuka dan juga tanah garapan. Tanah garapan ialah tanah terbuka yang dipakai untuk lahan pertanian. Jadi lahan bisa diartikan sebagai sebuah tempat ataupun tanah yang memilki luas tertentu yang dipakai untuk usaha pertanian. Lahan merupakan sumberdaya alam yang mempunyai fungsi yang sangat luas dalam memenuhi banyaknya kebutuhan manusia. Pengertian lahan sangat berbeda dari tanah. Tanah ialah salah satu aspek dari lahan setelah aspek iklim, hidrologi, relief dan vegetasi. Lahan ialah konsep yang sangat dinamis dan didalamnya terkandung unsur ekosistem. Tata guna lahan ialah campur tangan dari manusia yang permanen ataupun berkelanjutan untuk memenuhi dari kebutuhan dari manusia baik itu materil ataupun spiritual yaitu dari sumberdaya alam dan juga buatan yang secara serempak disebut dengan lahan (Wafda dalam Kamilah, 2013).

Adiraga dan Setiawan (2014) meneliti tentang Analisis Dampak Perubahan Curah Hujan, Luas Tambak Garam dan Jumlah Petani Garam Terhadap Produksi Usaha Garam Rakyat Di Kecamatan Juwana Kabupaten Pati Periode 2003-2012. Berdasarkan hasil dari penelitian ini bahwa Terdapat pengaruh negatif jumlah curah hujan terhadap jumlah produksi garam yang ada di Kota
Juwana. Hal ini artinya semakin tinggi dari jumlah curah hujan semakin rendah pula jumlah produksi garam yang ada di Kota Juwana. Variabel curah hujan ialah variabel yang sangat dominan dalam hal pengaruhnya dengan produksi garam yang ada di Kota Juwana. Tidak terdapat pengaruh dari luas tambak garam dengan jumlah produksi garam yang ada di Kota Juwana. Hal ini artinya banyak atau sedikitnya luas dari tambak garam tidak akan terlalu mempengaruhi besar atau kecilnya jumlah dari produksi garam yang ada di Kota Juwana. Tidak terdapat pengaruh dari jumlah petani garam dengan produksi garam yang ada di Kota Juwana. Hal ini artinya banyak atau sedikitnya jumlah dari petani tidak memiliki pengaruh dengan jumlah produksi garam yang ada di Kota Juwana.

\section{Tenaga Kerja}

Definisi tenaga kerja ialah Banyaknya orang yang bekerja untuk melakukan kegiatan usaha tambak, dalam satuan Jiwa. Menurut Dumairy dalam Takyuddin (2016) tenaga kerja merupakan penduduk yang punya umur di dalam batas usia kerja. Tujuan pemilihan dari batas umur tersebut, agar arti yang diberikan sebisa mungkin menggambarkan dari kenyataan dengan sebenarsebenarnya. Setiap negara di dunia memilih dengan batas umur yang berbeda pula dikarenakan situasi dari tenaga kerja di masing-masing negara itu juga beda, sehingga batasan dari usia kerja diantara negara pun menjadi berbeda. Di Indonesia, batas dari umur minimal dari tenaga kerja ialah 15 tahun tanpa adanya batas maksimal.

Turua et all (2014) meneliti tentang Analisis Pengaruh Luas Lahan, Tenaga Kerja, Bibit, Pakan Dan Pupuk Terhadap Produksi Ikan Nila Di Kelurahan Koya Timur Distrik Muara Tami. Berdasarkan hasil dari penelitian menunjukkan bahwa luas lahan mempunyai pengaruh kontribusi sebesar $54,8 \%$ terhadap produksi ikan nila di kelurahan koya timur dengan koefisien sebesar 1,204 dengan angka signifikan 0,000 lebih kecil dari pada kriteria signifikan $(0,05)$ yang berarti luas lahan berpengaruh signifikan terhadap produksi ikan nila di kelurahan koya timur. Dengan tingkat kepercayaan 95 persen. ( $\alpha=5$ persen). Tenaga kerja memiliki pengaruh kontribusi sebesar 9,3\% terhadap produksi ikan nila di kelurahan koya timur 
dengan nilai koefisien sebesar 0,398 dengan angka siignifikan 0,031 lebih kecil dari pada kriteria signifikan $(0,05)$ yang berarti tenaga kerja berpengaruh signifikan terhadap produksi ikan nila di kelurahan koya timur. Dengan tingkat kepercayaan 95 persen. Bibit memiliki pengaruh kontribusi sebesar $72,2 \%$ terhadap produksi ikan nila di kelurahan koya timur dengan nilai koefisien sebesar 1,316 dengan angka signifikan 0,000 lebih kecil dari pada kriteria signifikan $(0,05)$ yang berarti bibit berpengaruh signifikan terhadap produksi ikan nila di kelurahan koya timur. Dengan tingkat kepercayaan 95 persen. Pakan memiliki pengaruh kontribusi sebesar $1,6 \%$ terhadap produksi ikan nila di kelurahan koya timur dengan nilai koefisien sebesar 0,031 dengan angka signifikan 0,381 lebih besar dari kriteria signifikan $(0,05)$ yang berarti pakan tidak berpengaruh signifikan terhadap produksi ikan nila dikelurahan koya timur. Dengan tingkat kepercayaan 95 persen. Pupuk memiliki pengaruh kontribusi sebesar 72,2\% terhadap produksi ikan nila di kelurahan koya timur dengan nilai koefisien sebesar 1,316 dengan angka signifikan 0,000 lebih kecil dari pada kriteria signifikan $(0,05)$ yang berarti pupuk berpengaruh signifikan terhadap produksi ikan nila di kelurahan koya timur. Dengan tingkat kepercayaan 95 persen.

\section{Kerangka Konseptual}

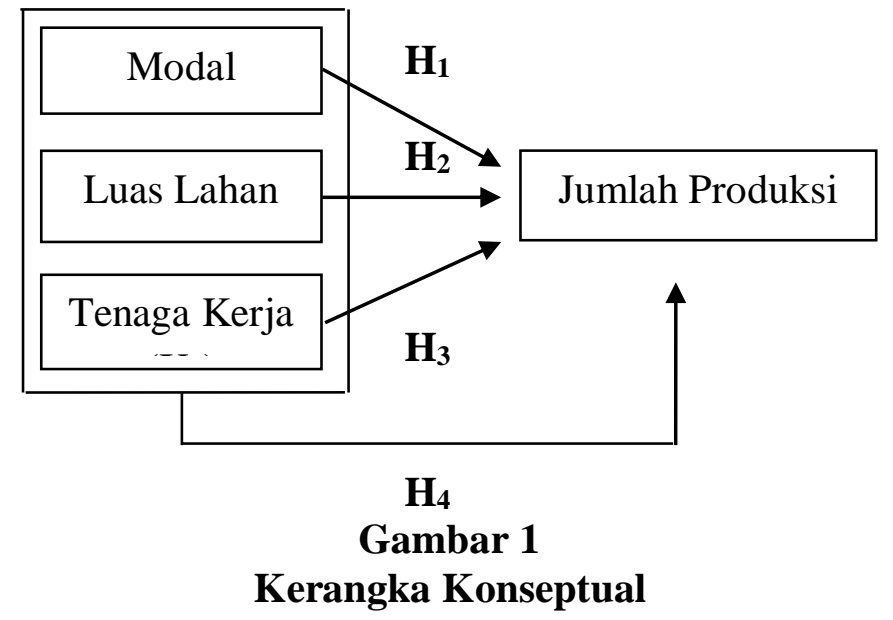

Berdasarkan Gambar 1 di atas, kerangka pemikiran dalam penelitian ini dapat dijelaskan, apakah modal, tenga kerja dan juga luas lahan berpengaruh dengan jumlah produksi tambak ikan di Gampong Batuphat Barat Kecamatan Muara Satu Kota Lhokseumawe. Dalam penelitian ini nantinya penulis menggunakan pengujian luji $t$, dimana uji $\mathrm{t}$ yaitu pengujian secara perindividu untuk mengetahui pengaruh variabel bebas yang dalam hal ini ialah luas lahan, modal dan juga tenaga kerja terhadap variabel terikat yang dalam hal ini ialah jumlah produksi tambak dan kemudian juga dilakukan pengujian uji $\mathrm{F}$, dimana uji $\mathrm{F}$ yaitu pengujian secara bersama-sama untuk mengetahui pengaruh variabel bebas (luas lahan, modal dan juga tenaga kerja) terhadap variabel terikat yang dalam hal ini adalah jumlah produksi tambak ikan.

\section{Hipotesis Penelitian}

Hipotesis penelitian adalah suatu dugaan yang perlu untuk di uji kebenarannya, biasanya sering sekali digunakan sebagai dasar pengambil keputusan untuk menyelesaikan masalah dalam sebuah penelitian. Untuk dapat mengarahkan pada hasil penelitian, dengan mengacu pada rumusan masalah, tinjauan teoritis dan penelitian sebelumnya yang telah diuraikan, hipotesis ini nantinya akan diuji kebenaranya dan hasil uji ini nantinya akan dapat digunakan sebagai masukan ataupun saran. Melihat perkembangan modal, luas lahan dan juga tenaga kerja pada usaha tambak ikan di Gampong Batuphat Barat Kecamatan Muara Satu Kota Lhokseumawe, maka penulis merumuskan hipotesis sebagai berikut:

$\mathrm{H}_{1}$ : Diduga modal berpengaruh positif dan juga signifikan terhadap jumlah produksi tambak ikan di Gampong Batuphat Barat Kecamatan Muara Satu Kota Lhokseumawe.

$\mathrm{H}_{2}$ : Diduga luas lahan berpengaruh positif dan juga signifikan terhadap jumlah produksi tambak ikan di Gampong Batuphat Barat Kecamatan Muara Satu Kota Lhokseumawe.

$\mathrm{H}_{3}$ : Diduga tenaga kerja berpengaruh positif dan juga signifikan terhadap jumlah produksi tambak ikan di Gampong Batuphat Barat Kecamatan Muara Satu Kota Lhokseumawe.

$\mathrm{H}_{4}$ : Diduga modal, luas lahan dan tenaga kerja berpengaruh positif dan juga signifikan terhadap jumlah produksi tambak ikan di Gampong Batuphat Barat Kecamatan Muara Satu Kota Lhokseumawe. 


\section{METODE PENELITIAN}

\section{Populasi dan Sampel}

Desain penelitian dilakukan dengan model analisis regresi linear berganda data primer. Menurut Sugiyono dalam Yudistira (2017) populasi ialah wilayah dari generalisasi yang terdiri atas; objek/subyek yang memiliki kuantitas dan juga karakteristik tertentu yang sudah ditetapkan oleh peneliti guna dipelajari dan juga kemudian ditarik kesimpulan.". Yang menjadi populasi pada penelitian ini adalah seluruh usaha tambak ikan yang ada di Gampong Batuphat Barat Kecamatan Muara Satu Kota Lhokseumawe. Adapun yang menjadi populasi pada penelitian ini ialah 30 orang yang merupakan pemilik usaha tambak ikan yang ada di Gampong Batuphat Barat Kecamatan Muara Satu Kota Lhokseumawe.

Menurut Sugiyono dalam Putri dan Nyoman (2017) sampel ialah bagian dari pada populasi yang nantinya diambil melalui cara-cara tertentu yang juga mempunyai karakteristik tertentu jelas dan juga lengkap yang dianggap dapat mewakili jumlah populasi. Dalam penentuan sampel pada penelitian ini ialah dengan menggunakan metode sensus. Metode sensus adalah sampel dari seluruh populasi. Sedangkan sampel yang dijadikan dalam penelitian ini ialah sebanyak 30 orang yang merupakan pemilik usaha tambak ikan yang ada di Gampong Batuphat Barat Kecamatan Muara Satu Kota Lhokseumawe. Jumlah sampel tersebut diperoleh berdasarkan teknik pengambilan sampel yaitu Metode Sensus, dimana metode tersebut digunakan untuk mengambil seluruh jumlah populasi dan sampel.

\section{Defisini Operasional Variabel}

Variabel adalah obyek penelitian, ataupun apa yang menjadi perhatian suatu penelitian. Definisi operasional variabel merupakan penjelasan dari variabel dependen (terikat) dan variabel independen (bebas), berikut adalah penjelasan masing-masing variabel dependen dan independen:

\section{Jumlah Produksi (Y)}

Besarnya jumlah ikan yang dihasilkan oleh usaha tambak dalam sekali panen, dalam satuan $\mathrm{Kg}$.

2. Modal $\left(\mathrm{X}_{1}\right)$

Biaya yang dikeluarkan oleh pemilik usaha untuk memperoleh hasil dan biaya tersebut merupakan biaya segala kebutuhan usaha yang diperlukan untuk proses mencapai hasil, dalam satuan Rupiah.

3. Luas Lahan $\left(\mathrm{X}_{2}\right)$

Besarnya lahan yang dimiliki pemilik usaha tambak ikan untuk melakukan kegiatan usaha tambak, dalam satuan Ha.

4. Tenaga Kerja $\left(\mathrm{X}_{3}\right)$

Banyaknya orang yang bekerja untuk melakukan kegiatan usaha tambak, dalam satuan Jiwa.

\section{Metode Analisis Data}

Metode analisis data yang dipakai didalam penelitian ini ialah metode kuantitatif yaitu dalam pengambilan data secara statistik untuk mempermudah perhitungannya dengan menggunakan data-data statistik. Untuk mengukur pengaruh luas lahan, modal dan juga tenaga kerja dengan jumlah produksi usaha tambak ikan di Gampong Batuphat Barat Kecamatan Muara Satu Kota Lhokseumawe digunakan model regresi linier berganda. Penggunaan regresi linier berganda ini dilakukan berdasarkan asumsi dasar bahwa jumlah produksi tambak ditentukan oleh variabel modal, luas lahan dan juga tenaga kerja. Adapun formulasi model regresi linier berganda di dalam penelitian ini ialah sebagai berikut:

$$
Y=\beta_{0}+\beta_{1} X_{1}+\beta_{2} X_{2}+\beta_{3} X_{3}+e
$$

Persamaan di atas dalam penelitian ini yang akan menjelaskan keterkaitan variabel independen dengan dependen, dikarenakan variabel dalam bentuk satuan $\mathrm{Kg}$ untuk mengukur besarnya jumlah produksi, variabel dalam bentuk satuan Rp untuk mengukur besarnya modal, variabel dalam bentuk satuan Ha untuk mengukur besarnya luas lahan dan variabel dalam bentuk satuan jiwa untuk mengukur banyaknya jumlah tenaga kerja, maka selanjutnya untuk menyeragamkan menjadi satu ukuran yang sama bagi masing-masing variabel tersebut variabel di atas diubah bentuknya menjadi Log, dengan demikian persamaannya berubah menjadi:

$\log Y=\beta_{0}+\beta_{1} \log X_{1}+\beta_{2} \log X_{2}+\beta_{3} \log X_{3}+e$

Dimana:

$\log \mathrm{Y}=$ Jumlah produksi tambak ikan 
$\beta_{0} \quad=$ Konstanta

$\beta_{1}, \beta_{2}, \beta_{3}=$ Koefisien regresi variabel

$\operatorname{LogX}_{1} \quad=$ Modal

$\log _{2} \quad=$ Luas Lahan

$\log _{3} \quad=$ Tenaga Kerja

$\mathrm{e}=$ Error term (Variabel penganggu)

\section{Uji Normalitas}

Uji normalitas bertujuan guna menguji apakah di dalam model dari regresi, variabel residual atau pengganggu memiliki distribusi normal. Jika terdapat asumsi normalitas, maka nantinya residual akan berdistribusi secara normal dan juga independen, yaitu perbedaan antar nilai prediksi dengan score yang sebenarnya atau error akan berdistribusi secara simetri di sekitar nilai means sama dengan nol (Ghozali dalam Mahardika dan Artini, 2017). Untuk uji normalitas data penulis melihat pada nilai Jarque-Bera. Menurut Firmansyah (2015) normalitas bisa dideteksi dengan melihat nilai Jarque Bera dan juga $\mathrm{X}^{2}$ tabel , yaitu:

1. Jika nilai JB $>X^{2}$ tabel, maka residualnya berdistribusi tidak normal.

2. Jika nilai JB $<\mathrm{X}^{2}$ tabel, maka residualnya berdistribusi normal.

\section{Uji Asumsi Klasik}

\section{Uji Heteroskedastisitas}

Ghozali dalam Mahardika dan Artini (2017) menyatakan bahwa pengujian heteroskedastisitas bertujuan untuk mengetahui apakah di dalam model regresi sudah terjadi ketidaksamaan varian dan juga residual antara satu pengamatan dengan pengamatan yang lainnya. Jika varian dan juga residual pada suatu pengamatan ke pengamatan yang lainnya tetap maka disebut homokedastisitas, jika berbeda maka disebut heteroskedastisitas. Model regresi yang baik ialah model regresi yang mempunyai kesamaan variance residual suatu periode pengamatan dengan pengamatan yang lain. Untuk melihat heteroskedastisitas, peneliti dapat menggunakan uji white, guna mendeteksi adanya heterokedastisitas atau tidak maka dapat dilihat dengan membandingkan nilai $\mathrm{R}$-squared dan $\mathrm{X}^{2}$ tabel:

1. Jika nilai Obs*R-squared $>X^{2}$ tabel, maka residualnya terkena heterokedastisitas.
2. Jika nilai Obs*R-squared $<\mathrm{X}^{2}$ tabel, maka residualnya terbebas dari heterokedastisitas.

\section{Uji Multikolinearitas}

Menurut Ghozali dalam Mahardika dan Artini (2017) uji multikoliniritas bertujuan guna menguji apakah model regresi ditemukan terdapat korelasi antar variabel bebasnya (independen). Selain itu guna mendeteksi multikoliniearitas bertujuan guna menghindari bias di dalam pengambilan keputusan nantinya mengenai pengaruh uji parsial di masingmasing variabel bebas dengan variabel terikat. Model analisis regresi yang baik sudah seharusnya tidak ada korelasi antar variabel independen ataupun bebas. Jika variabel independen atau bebas saling berhubungan atau berkorelasi, maka dengan begitu variabel-variabel bebas ini tidak ortogonal. Variabel ortogonal ialah variabel independen ataupun bebas yang mempunyai nilai korelasi antar variabel independen atau bebasnya sama dengan nol.

Menurut Sanjaya dan Pratiwi (2018) multikolinearitas dapat dideteksi dengan melihat nilai dari centered VIF dengan pengujian variance inflation factor, jika nilai centered VIF tidak lebih dari 10, maka model tersebut bisa dikatakan terbebas dari asumsi multikolinieritas.

\section{Uji Hipotesis}

\section{Uji t}

Uji t dilakukan guna melihat signifikansi dari pengaruhnya variabel bebas secara individu (satusatu) terhadap variabel terikat dengan anggapan variabel bebas lainnya adalah konstan. Pengujian yang digunakan dengan kriteria keputusan jika $t_{\text {hitung }}$ lebih besar dari tabel maka variabel bebas secara parsial mempunyai pengaruh terhadap variabel terikat dan sebaliknya Apabila nilai thitung lebih kecil dari nilai tabel maka variabel bebas secara parsial tidak mempunyai pengaruh terhadap variabel terikat. (Ghozali dalam Mahardika dan Artini, 2017).

\section{Uji F}

Uji F dilakukan guna mengetahui apakah variabel-variabel bebas secara keseluruhan secara statistik mempengaruhi variabel dependen. Apabila nilai $F_{\text {hitung }}$ lebih besar dari nilai $F_{\text {tabel }}$ maka variabel-variabel independen secara keseluruhan 
berpengaruh terhadap variabel dependen, dan sebaliknya Apabila nilai $F_{\text {hitung }}$ lebih kecil dari nilai $F_{\text {tabel maka variabel-variabel bebas secara }}$ keseluruhan tidak mempunyai pengaruh terhadap variabel terikat. (Ghozali dalam Mahardika dan Artini, 2017).

\section{Koefisien Determinasi}

Menurut Ghozali dalam Jayantara dan Dharmadiaksa (2016) koefisien determinasi (Adjusted $R^{2}$ ) pada intinya guna mengukur seberapa jauh dari kemampuan model di dalam menerangkan variasi dari variabel terikat. Nilai koefisien determinasi ialah antara nol dan juga satu. Nilai $\mathrm{R}^{2}$ yang kecil artinya kemampuan variabel-variabel bebas atau independen di dalam menerangkan variasi dari variabel terikat atau dependen sangat terbatas. Jika nilai yang hampir mendekati satu artinya variabel-variabel bebas atau independen memberikan hampir keseluruhan dari informasi yang dibutuhkan guna memprediksi dari variasi variabel terikat. Jika di dalam uji empiris diperoleh nilai dari adjusted $\mathrm{R}^{2}$ negatif, maka nilai dari adjusted $R^{2}$ dianggap nol. Secara matematis jika nilai $\mathrm{R}^{2}=1$, maka adjusted $R^{2}=\mathrm{R}^{2}=1$ sedangkan jika nilai $\mathrm{R}^{2}=0$, maka adjusted $R^{2}=(1-$ $\mathrm{k}) /(\mathrm{n}-\mathrm{k})$. Jika $\mathrm{k}>1$, maka adjusted $R^{2}$ akan bernilai negatif.

\section{HASIL PENELTIAN DAN PEMBAHASAN}

Luas daratan di Aceh ialah 57.365,67 Km², daratan Aceh dikelilingi oleh Samudera Indonesia di wilayah Barat-Selatan Aceh, dan juga Selat Malaka serta perairan Andaman di wilayah UtaraTimur Aceh, dengan panjang dari garis pantai sebesar 2.666,27 $\mathrm{Km}^{2}$. Sedangkan luas dari perairannya ialah mencapai $295.370 \mathrm{Km}^{2}$, yang terdiri dari pada perairan teritorial dan juga kepulauan sebesar $56.563 \mathrm{Km}^{2}$, serta perairan Zona Ekonomi Eksklusif (ZEE) $238.807 \mathrm{Km}^{2}$. Potensi dari lestari diperkirakan ialah sebesar 272.700 Ton/Tahun, jumlah dari kapal penangkap ikan ialah sebanyak 16.701 unit dan juga jumlah dari nelayan ialah sebanyak 64.466 orang. Luas lahan tambak diperkirakan seluas 53.000 Ha. (Damanhur dan Rahayu, 2017).

\section{Hasil Uji Normalitas}

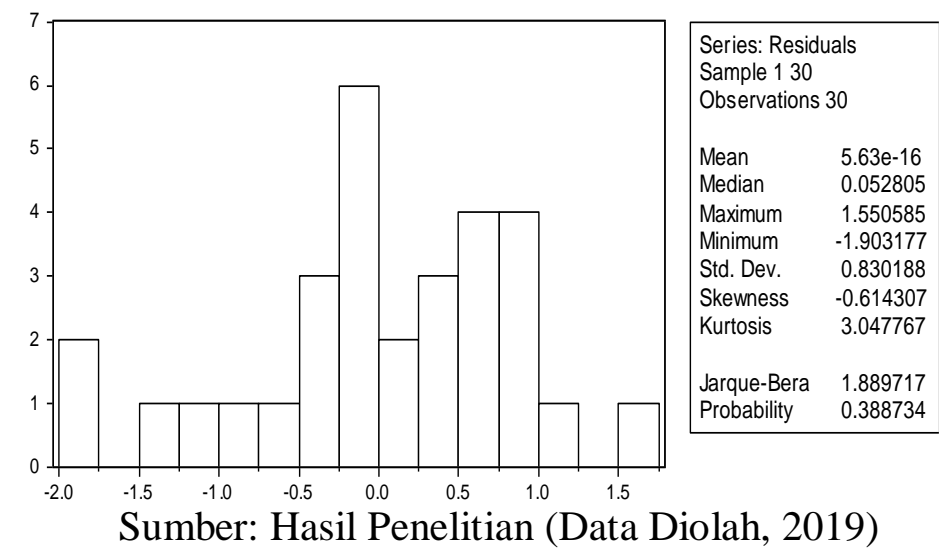

\section{Gambar 2 Uji Normalitas}

Berdasarkan grafik yang telah diolah pada Gambar 4.2 terlihat bahwa nilai JB $<\mathrm{X}^{2}$ yaitu $1.889717<42.55697$. Dapat disimpulkan bahwa pada model regresi ini terdistribusi normal. Maka dapat pastikan bahwa data di dalam penelitian ini sudah baik dikarenakan variabel residual telah terdistribusi normal.

\section{Hasil Uji Asumsi Klasik \\ Hasil Uji Heteroskedastisitas}

Tabel 2

Uji Heteroskedastisitas

\begin{tabular}{|l|r|}
\hline \multicolumn{2}{|c|}{ Heteroskedasticity Test: White } \\
\hline F-statistic & 1.071426 \\
Obs*R-squared & 9.759023 \\
Scaled explained SS & 7.505181 \\
\hline \multicolumn{2}{|c|}{$\mathrm{X}_{\text {tabel }}^{2}=42.55697$} \\
\hline
\end{tabular}

Sumber: Hasil Penelitian (Data Diolah, 2019)

Dari hasil Tabel di atas tampak bahwa nilai obs* $R$-square untuk hasil adalah sebesar 9.759023 dan nilai $\mathrm{X}^{2}$ tabel dengan derajat kepercayaan 5 persen adalah sebesar 42.55697. Karena nilai $o b s^{*}$ $R$-squared (9.759023) < $\mathrm{X}^{2}$ tabel (42.55697) maka disimpulkan model di atas terbebas dari gejala heterokedastisitas. Maka dapat dipastikan bahwa data di dalam penelitian ini sudah baik dikarenakan memiliki kesamaan varian dan residual dalam satu pengamatan dengan pengamatan lainnya.

\section{Hasil Uji Multikolinearitas}

Tabel 3

Uji Multikolinearitas

\begin{tabular}{|c|c|c|c|}
\hline Variabel & $\begin{array}{c}\text { Coefficient } \\
\text { Variance }\end{array}$ & $\begin{array}{c}\text { Uncentered } \\
\text { VIF }\end{array}$ & $\begin{array}{c}\text { Centered } \\
\text { VIF }\end{array}$ \\
\hline $\mathrm{C}$ & 3.841484 & 149.9143 & NA \\
$\log \left(\mathrm{X}_{1}\right)$ & 0.015215 & 160.6408 & 1.243653 \\
\hline
\end{tabular}




\begin{tabular}{|l|l|l|l|}
$\log \left(\mathrm{X}_{2}\right)$ & 0.153989 & 1.608701 & 1.052681 \\
$\log \left(\mathrm{X}_{3}\right)$ & 0.215728 & 2.160512 & 1.258123 \\
\hline
\end{tabular}

Sumber: Hasil Penelitian (Data Diolah, 2019)

Berdasarkan Tabel 3, nilai Centered VIF di bawah 10 dan menunjukkan tidak terjadi multikolinieritas antara variabel bebas dalam model regresi, Hasil olah data diketahui bahwa nilai Centered VIF variabel Modal $\left(\mathrm{X}_{1}\right)$ sebesar 1.243653, Luas Lahan $\left(\mathrm{X}_{2}\right)$ sebesar 1.052681 dan juga Tenaga Kerja $\left(X_{3}\right)$ sebesar 1.258123. Maka disimpulkan bahwa data di dalam penelitian ini sudah baik dikarenakan tidak memiliki hubungan antar variabel bebas.

\section{Analisis Regresi Linear Berganda}

Berdasarkan perbandingan hasil penelitian sebelumnya dan teori yang ada, maka peneliti melakukan analisis regresi linear berganda antara variabel bebas dan juga terikat dalam penelitian ini. Dimana yang menjadi variabelnya adalah Jumlah Produksi (Y), Modal $\left(\mathrm{X}_{1}\right)$, Luas Lahan $\left(\mathrm{X}_{2}\right)$ dan juga Tenaga Kerja $\left(\mathrm{X}_{3}\right)$. Untuk mengetahui hasil dari penelitian ini dapat dilihat output regresi linear berganda yang akan ditampikan pada Tabel 4 berikut ini:

\section{Tabel 4}

Analisis Regresi Linear Berganda

\begin{tabular}{|rrrr|}
\hline \multicolumn{1}{|c}{ Variable } & Coefficient & t-Statistic & Prob. \\
\hline $\mathrm{C}$ & 2.447102 & 1.248540 & 0.2230 \\
$\operatorname{LogX}_{1}$ & 0.289577 & 2.347659 & 0.0268 \\
$\operatorname{LogX}_{2}$ & 0.486271 & 1.239179 & 0.2263 \\
$\operatorname{LogX}_{3}$ & 0.527437 & 1.135580 & 0.2665 \\
\hline R-squared & 0.362700 F-statistic & 4.932373 \\
Adjusted R- & 0.289165 Prob(F- & 0.007639 \\
squared & \multicolumn{2}{c}{ statistic) } \\
ttabel $^{2}$ & 2.056 F Fabel & 2.98 \\
$\mathrm{X}_{\text {tabel }}$ & 42.55697 & \\
\hline
\end{tabular}

Sumber: Hasil Penelitian (Data Diolah, 2019)

Berdasarkan data dari tabel 4 di atas apabila dimasukkan dalam model penelitian, maka persamaan regresi linear berganda (multiple regression linear) adalah sebagai berikut:

\section{$\log \mathrm{Y}=2.447102+0.289577 \log \mathrm{X}_{1}+$ $0.486271 \log X_{2}+0.527437 \log X_{3}$}

Dari persamaan model regresi di atas maka hasil penelitian dapat dinyatakan sebagai berikut: Nilai konstanta sebesar 2.447102 yang berarti bahwa jika variabel Modal $\left(\mathrm{X}_{1}\right)$, Luas Lahan $\left(\mathrm{X}_{2}\right)$ dan juga Tenaga Kerja $\left(\mathrm{X}_{3}\right)$ tidak dimasukkan dalam penelitian ini, maka jumlah produksi pada usaha tambak ikan di Gampong Batuphat Barat Kecamatan Muara Satu Kota Lhokseumawe akan mengalami penurunan sebesar 2,45\%. Selanjutnya diketahui nilai koefisien variabel Modal $\left(\mathrm{X}_{1}\right)$ sebesar 0.289577 yang berarti bahwa apabila Modal $\left(\mathrm{X}_{1}\right)$ meningkat $1 \%$ maka jumlah produksi pada usaha tambak ikan di Gampong Batuphat Barat Kecamatan Muara Satu Kota Lhokseumawe dapat mengalami peningkatan sebesar $0.29 \%$. Kemudian diketahui nilai koefisien variabel Luas Lahan $\left(\mathrm{X}_{2}\right)$ sebesar 0.486271 yang berarti bahwa apabila Luas Lahan $\left(\mathrm{X}_{2}\right)$ meningkat $1 \mathrm{~m}^{2}$ maka jumlah produksi pada usaha tambak ikan di Gampong Batuphat Barat Kecamatan Muara Satu Kota Lhokseumawe dapat mengalami peningkatan sebesar 0,48\%. Kemudian diketahui nilai koefisien variabel Tenaga Kerja $\left(\mathrm{X}_{3}\right)$ sebesar 0.527437 yang berarti bahwa apabila Tenaga Kerja $\left(\mathrm{X}_{3}\right)$ meningkat 1 Orang maka jumlah produksi pada usaha tambak ikan di Gampong Batuphat Barat Kecamatan Muara Satu Kota Lhokseumawe dapat mengalami peningkatan sebesar $0,53 \%$.

\section{Hasil Uji Hipotesis Hasil Uji t}

Hasil pembuktian secara parsial ataupun uji $\mathrm{t}$ bisa dilihat pada Tabel 4. Dari hasil pengujian sebagaimana yang ditunjukan pada Tabel 4 maka dapat dilihat bahwa Modal $\left(\mathrm{X}_{1}\right)$ memilki nilai thitung $>\mathrm{t}_{\text {tabel }}$ yaitu $2.347659>2.056$ dengan nilai signifikansi $0.0268<0,05$, berarti secara parsial Modal $\left(\mathrm{X}_{1}\right)$ berpengaruh positif dan juga signifikan terhadap jumlah produksi usaha tambak ikan di Gampong Batuphat Barat Kecamatan Muara Satu Kota Lhokseumawe. Selanjutnya dapat dilihat bahwa Luas Lahan $\left(\mathrm{X}_{2}\right)$ memilki nilai $\mathrm{t}_{\text {hitung }}<\mathrm{t}_{\text {tabel }}$ yaitu $1.239179<2.056$ dengan nilai signifikansi $0.2263>0,05$, berarti secara parsial Luas Lahan $\left(\mathrm{X}_{2}\right)$ tidak berpengaruh signifikan dan positif terhadap jumlah produksi usaha tambak ikan di Gampong Batuphat Barat Kecamatan Muara Satu Kota Lhokseumawe. Kemudian dapat dilihat bahwa Tenaga Kerja $\left(\mathrm{X}_{3}\right)$ memilki nilai thitung <

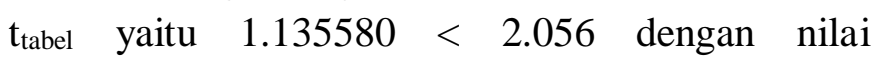
signifikansi $0.2665>0,05$, berarti secara parsial Tenaga Kerja $\left(\mathrm{X}_{3}\right)$ tidak berpengaruh signifikan dan positif terhadap jumlah produksi usaha tambak 
ikan di Gampong Batuphat Barat Kecamatan Muara Satu Kota Lhokseumawe.

\section{Hasil Uji F}

Hasil pembuktian secara simultan (Uji F) bisa dilihat pada Tabel 4. Berdasarkan hasil pengujian yang dilakukan terdapat pada Tabel 4, maka dapat dilihat bahwa Modal $\left(\mathrm{X}_{1}\right)$, Luas Lahan $\left(\mathrm{X}_{2}\right)$ dan juga Tenaga Kerja $\left(X_{3}\right)$ memiliki nilai $F_{\text {hitung }}>F_{\text {tabel }}$ yaitu $4.932373>2.98$ dengan nilai signifikansi sebesar $0.007639<0,05$, berarti secara serempak atau bersama-sama Modal $\left(\mathrm{X}_{1}\right)$, Luas Lahan $\left(\mathrm{X}_{2}\right)$ dan juga Tenaga Kerja $\left(\mathrm{X}_{3}\right)$ berpengaruh positif dan juga signifikan terhadap jumlah produksi usaha tambak ikan di Gampong Batuphat Barat Kecamatan Muara Satu Kota Lhokseumawe. Hal ini sejalan dengan penelitian terdahulu yang menjadi landasan teori dalam penelitian ini yang dilakukan oleh Dewi dan Yuliarmi (2017) meneliti tentang "Pengaruh Modal, Tenaga Kerja, Dan Luas Lahan Terhadap Jumlah Produksi Kopi Arabika Di Kecamatan Kintamani Kabupaten Bangli” yang menyatakan bahwa secara simultan modal, luas lahan dan juga tenaga kerja mempunyai pengaruh yang signifikan terhadap jumlah produksi kopi arabika di Kecamatan Kintamani Kabupaten Bangli.

\section{Koefisien Determinasi}

Dalam analisa determinasi ini menggunakan nilai adjustted $\mathrm{R}$-squared untuk mengukur sejauh mana Modal $\left(\mathrm{X}_{1}\right)$, Luas Lahan $\left(\mathrm{X}_{2}\right)$ dan jugaTenaga Kerja $\left(\mathrm{X}_{3}\right)$ menjelaskan pengaruhnya terhadap jumlah produksi usaha tambak ikan di Gampong Batuphat Barat Kecamatan Muara Satu Kota Lhokseumawe. Dapat dilihat pada nilai adjustted $R$-squared, berdasarkan hasil pengujian yang ada pada Tabel 4 bahwa nilai adjustted $R$ squared sebesar 0.289165 yang artinya pengaruh variabel Modal $\left(\mathrm{X}_{1}\right)$, Luas Lahan $\left(\mathrm{X}_{2}\right)$ dan juga Tenaga Kerja $\left(\mathrm{X}_{3}\right)$ terhadap jumlah produksi usaha tambak ikan di Gampong Batuphat Barat Kecamatan Muara Satu Kota Lhokseumawe adalah sebesar 0.289165 atau $28,91 \%$, sementara sisanya yaitu $71,09 \%$ dipengaruhi oleh variabel lainnya yang tidak dimasukkan dalam model penelitian ini.

\section{Pembahasan}

\section{Pengaruh Modal Terhadap Jumlah Produksi}

Berdasarkan hasil pengujian bahwa modal berpengaruh positif dan juga signifikan terhadap jumlah produksi usaha tambak ikan di Gampong Batuphat Barat Kecamatan Muara Satu Kota Lhokseumawe. Hal ini sejalan dengan penelitian terdahulu yang dilakukan oleh Dewi dan Yuliarmi (2017) tentang Pengaruh Modal, Tenaga Kerja, Dan Luas Lahan Terhadap Jumlah Produksi Kopi Arabika Di Kecamatan Kintamani Kabupaten Bangli yang menyatakan bahwa modal berpengaruh signifikan terhadap jumlah produksi. Menurut Tambunan dalam Dewi dan Yuliarmi (2017) modal adalah faktor produksi penting untuk setiap usaha, baik usaha kecil, menengah maupun besar yang dapat meningkatkan jumlah produksi. Hal ini dipertegas oleh Daniel dalam Dewi dan Yuliarmi (2017), modal merupakan faktor penting dalam usaha untuk membiayai produksi, biaya tenaga kerja, kekurangan modal dapat menyebabkan rendahnya hasil poduksi.

\section{Pengaruh Luas Lahan Terhadap Jumlah Produksi}

Berdasarkan hasil pengujian bahwa luas lahan tidak berpengaruh signifikan namun positif terhadap jumlah produksi usaha tambak ikan di Gampong Batuphat Barat Kecamatan Muara Satu Kota Lhokseumawe. Variabel luas lahan dalam penelitian ini merupakan faktor yang tidak berpengaruh terhadap jumlah produksi pada usaha ikan tambak, namun arah hubungannya kedua variabel tersebut bersifat positif. Hasil ini menjelaskan bahwa peningkatan luas lahan belum tentu meningkatkan jumlah produksi pada usaha ikan tambak.

Hasil ini memberikan gambaran bahwa luas lahan yang lebih luas yang digunakan untuk memelihara ikan tambak belum sepenuhnya memberikan produksi ikan tambak yang lebih banyak. Hal ini berbanding terbalik dengan dugaan sebelumnya yang selama ini menjadi permasalahan penelitian. Tidak adanya pengaruh signifikan ini dikarenakan oleh pemanfaatan luas lahan yang tidak optimal oleh petani tambak. Belum optimalnya pemanfaatan lahan oleh petani tambak disebabkan tidak seimbangnya antara modal yang dikeluarkan oleh pengusaha tambak dan lahan yang 
ada. Seharusnya luas lahan yang dimiliki oleh pemilik tambak ini haruslah diimbangi dengan modal yang mencukupi untuk memenuhi bibit ikan yang banyak sehingga pada usaha tambak ini dapat menghasilkan hasil produksi maksimal. Artinya besarnya luas lahan yang dimiliki oleh pemilik usaha tambak tanpa didukung oleh modal yang mencukupi untuk memenuhi bibit ikan yang maksimal sesuai dengan luas lahan yang ada maka hasil yang didapat juga tidak akan mencapai maksimal.

Hal ini sejalan dengan dengan penelitian terdahulu yang dilakukan oleh Adiraga Adiraga dan Setiawan (2014) tentang Analisis Dampak Perubahan Curah Hujan, Luas Tambak Garam Dan Jumlah Petani Garam Terhadap Produksi Usaha Garam Rakyat Di Kecamatan Juwana Kabupaten Pati Periode 2003-2012 yang menyatakan bahwa luas lahan tidak berpengaruh signifikan terhadap jumlah produksi.

\section{Pengaruh Tenaga Kerja Terhadap Jumlah} Produksi

Berdasarkan hasil pengujian bahwa tenaga kerja tidak berpengaruh signifikan namun positif terhadap jumlah produksi usaha tambak ikan di Gampong Batuphat Barat Kecamatan Muara Satu Kota Lhokseumawe. Hal ini sejalan dengan penelitian terdahulu yang dilakukan oleh Habib (2013) tentang Analisis Faktor - Faktor Yang Mempengaruhi Produksi Jagung yang menyatakan bahwa tenaga kerja tidak berpengaruh signifikan terhadap jumlah produksi. Menurut Habib (2013) tenaga kerja ialah faktor produksi yang sangat perlu untuk diperhitungkan pada proses produksi dalam jumlah yang cukup, bukan hanya dilihat dari tersedianya tenaga kerja saja, akan tetapi kualitas dan juga macam tenaga kerja juga perlu diperhatikan. Jumlah dari tenaga kerja ini masih banyak sekali dipengaruhi dan juga dikaitkan dengan kualitas dari tenaga kerja, jenis kelamin, musim dan juga upah tenaga kerja. Bila kualitas tenaga kerja, ini tidak diperhatikan, maka nantinya akan terjadi kemacetan di dalam proses produksi.

\section{KESIMPULAN DAN SARAN \\ Kesimpulan}

Berdasarkan hasil penelitian yang telah dilakukan, maka dapat disimpulkan bahwa:

1. Secara simultan menyatakan bahwa variabel Modal $\left(\mathrm{X}_{1}\right)$, Luas Lahan $\left(\mathrm{X}_{2}\right)$ dan Tenaga Kerja $\left(\mathrm{X}_{3}\right)$ secara bersama-sama (serempak) berpengaruh positif dan signifikan terhadap jumlah produksi usaha tambak ikan di Gampong Batuphat Barat Kecamatan Muara Satu Kota Lhokseumawe.

2. Secara parsial menyatakan bahwa variabel Modal $\left(\mathrm{X}_{1}\right)$ berpengaruh positif dan signifikan terhadap jumlah produksi usaha tambak ikan di Gampong Batuphat Barat Kecamatan Muara Satu Kota Lhokseumawe, sedangkan variabel Luas Lahan $\left(\mathrm{X}_{2}\right)$ dan Tenaga Kerja $\left(\mathrm{X}_{3}\right)$ tidak berpengaruh signikan dan positif terhadap jumlah produksi usaha tambak ikan di Gampong Batuphat Barat Kecamatan Muara Satu Kota Lhokseumawe.

\section{Saran}

Berdasarkan hasil penelitian dan kesimpulan di atas, maka penulis memberikan beberapa saran sebagai berikut:

1. Pemerintah Kota Lhokseumawe sebaiknya dapat memberikan bantuan maupun penyuluhan untuk para pelaku usaha tambak di Kota Lhokseumawe khususnya di Gampong Batuphat Barat, dikarenakan sektor pertanian melalui tani tambak merupakan salah satu sektor yang memiliki potensi dan memberikan sumbangsih bagi peningkatan pertumbuhan ekonomi di Kota Lhokseumawe. Jika potensi ini terus dikembangkan tidak menutup kemungkinan tani tambak akan menjadi potensi yang diunggulkan di Kota Lhokseumawe.

2. Bagi peneliti selanjutnya yang ingin meneliti tentang Pengaruh modal, luas lahan dan tenaga kerja terhadap jumlah produksi usaha tambak ikan. Ada baiknya menambah variabelvariabel lain untuk diteliti, karena sebenarnya cukup banyak faktor-faktor lain yang mempengaruhi jumlah produksi, tidak hanya modal, luas lahan dan tenaga kerja. 


\section{DAFTAR PUSTAKA}

[1] Adiraga, Y., dan Setiawan, A. H. (2014). Analisis Dampak Perubahan Curah Hujan, Luas Tambak Garam dan Jumlah Petani Garam Terhadap Produksi Usaha Garam Rakyat Di Kecamatan Juwana Kabupaten Pati Periode 2003-2012. Diponegoro Journal Of Economics, 3(1), 1-13.

[2] Damanhur, dan Rahayu, S. (2017). Analisis Aplikasi Akad Ijarah terhadap Pendapatan Petani Tambak Budidaya Ikan Bandeng di Kecamatan Samudera Kabupaten Aceh Utara. Jurnal Visioner Dan Strategis, 6(1), 11-21.

[3] Dewi, I. A. N. U., dan Yuliarmi, N. N. (2017). Pengaruh Modal, Tenaga Kerja, dan Luas Lahan Terhadap Jumlah Produksi Kopi Arabika Di Kecamatan Kintamani Kabupaten Bangli. E-Jurnal EP Unud, 6(6), 1127-1156.

[4] Firmansyah, Z. (2015). Analisis Pengaruh Umur, Pendidikan, Dan Upah Terhadap Produktivitas Tenaga Kerja. Economics Development Analysis Journal, 4(1), 91-97.

[5] Habib, A. (2013). Analisis Faktor-Faktor Yang Mempengaruhi Produksi Jagung. Jurnal Agrium, 18(1), 79-87.

[6] Humamy, H. F. (2013). Analisis Usaha Tambak Polikultur Kepiting, Ikan Nila Di Desa Paluh Manan Kecamatan Hamparan Perak Kabupaten Deli Serdang. Journal On Social Economic Of Agriculture And Agribusiness, 2(2), 1-12.

[7] Jayantara, I. K., dan Dharmadiaksa, I. B. (2016). Pengaruh Kemampuan Teknik Pemakai Dan Efektivitas Sistem Informasi Akuntansi (SIA) Terhadap Kinerja Individual. E-Jurnal Akuntansi Universitas Udayana, 17(3), 2145-2170.

[8] Kamilah, A. (2013). Analisis Ekonomi Alih Fungsi Lahan Pertanian Di Kota Bekasi (Kasus Kecamatan Bekasi Utara Dan Bantar Gebang). CEFARS: Jurnal Agribisnis Dan Pengembangan Wilayah, 5(1), 36-49.

[9] Mahardika, I. N. F., dan Artini, L. G. S. (2017). Pengaruh Rasio Pasar Dan Rasio Profitabilitas Terhadap Return Saham Perusahaan Di Bursa Efek Indonesia. E-Jurnal Manajemen Unud, 6(4), 1877-1905.

[10]Phahlevi, R. (2013). Faktor - Faktor Yang Mempengaruhi Pendapatan Petani Padi Sawah Di Kota Padang Panjang. Jurnal Kajian Ekonomi Dan Pembangunan, 1(2), 1-22.

[11]Putri, C. C., dan Nyoman, I. B. (2017). Pengaruh Desain Dan Kualitas Produk Terhadap Kepuasan Konsumen Melalui Kepuasan Pembelian Laptop Asus. Jurnal
Manajemen Dewantara, 1(1), 110-122.

[12] Sanjaya, S., dan Pratiwi, N. (2018). Pengaruh Tingkat Suku Bunga, Kurs dan Inflasi Terhadap Jakarta Islamic Index (JII). JEBI (Jurnal Ekonomi Dan Bisnis Islam), 3(1), 4758.

[13] Susilo, H. (2007). Analisis Ekonomi Usaha Budidaya Tambak dan Faktor-Faktor Yang Mempengaruhi Produksi. Jurnal Ekonomi Pertanian Dan Pembangunan, 4(2), 19-23.

[14] Takyuddin, M. (2016). Analisis Penyerapan Tenaga Kerja Pada Usaha Percetakan Foto Copy Di Kota Kendari. Jurnal Ekonomi (JE), $1(1), 80-89$.

[15]Turua, F. Z., Subyantoro, K., dan Ratang, S. A. (2014). Analisis Pengaruh Luas Lahan, Tenaga Kerja, Bibit, Pakan Dan Pupuk Terhadap Produksi Ikan Nila Di Kelurahan Koya Timur Distrik Muara Tami. Jurnal Kajian Ekonomi Dan Studi Pembangunan, I(3), 52-67.

[16] Yudistira. (2017). Literasi Informasi Pustakawan di Perpustakaan Fakultas Teknik UGM Menggunakan Pengembangan Model The BIG6. Berkala Ilmu Perpustakaan Dan Informasi, 13(1).

[17] Yusminar, C. (2018). Potensi Kelautan \& Perikanan di Aceh 2018. Dinas Kelautan Dan Perikanan Provinsi Aceh, 1-24. 
